\title{
Rancang Bangun Mesin Pemotong Styrofoam 3 Axis Menggunakan Hot Cutting Pen dengan Kontrol PID
}

\author{
Putut Dwi Wijaya, Muhammad Rivai, Tasripan \\ Departemen Teknik Elektro, Fakultas Teknologi Elektro, Institut Teknologi Sepuluh Nopember \\ E-mail:muhammad_rivai@ee.its.ac.id
}

\begin{abstract}
Abstrak-Perkembangan industri kreatif styrofoam semakin pesat. Pemotongan styrofoam secara manual sangat sulit dan tidak bisa konsisten. Dibutuhkan mesin pemotong styrofoam yang bisa memotong secara otomatis. Oleh karena itu, pada penelitian ini penulis membuat mesin pemotong styrofoam 3 axis menggunakan hot cutting pen yang dapat memotong dari starting point manapun sesuai dengan kehendak operator, sehingga bisa memotong lebih efektif. Pada aktuator terdapat sistem kontrol suhu dengan metode PID agar selama proses pemotongan suhu tetap stabil sehingga hasil potongan rapi dan konsisten. Untuk mengontrol keseluruhan kerja mesin, digunakan mikrokontroler arduino. Pemotongan dilakukan dengan mengirimkan file $g$-code kepada mikrokontroler melalui software Universal G-code Sender, kemudian mikrokontroler mengirimkan sinyal untuk menggerakkan driver motor dan driver motor menggerakkan motor stepper sehingga dihasilkan gerakan aktuator sesuai dengan gambar pada file g-code. Setelah dilakukan pengujian, didapatkan hasil bahwa kontrol suhu hot cutting pen menggunakan PID masih menghasilkan lebar osilasi sebesar $11^{\circ}$ Celcius. Pada pemotongan styrofoam $1 \mathrm{~cm}$ diperlukan suhu $290^{\circ}$ Celcius dan feed rate $300 \mathrm{~mm} / \mathrm{min}$, styrofoam $1,5 \mathrm{~cm}$ diperlukan suhu $300^{\circ}$ Celcius dan feed rate $300 \mathrm{~mm} / \mathrm{min}$, styrofoam $2 \mathrm{~cm}$ diperlukan suhu $310^{\circ}$ Celcius dan feed rate $300 \mathrm{~mm} / \mathrm{min}$, styrofoam $3 \mathrm{~cm}$ diperlukan suhu $330^{\circ}$ Celcius dan feed rate $300 \mathrm{~mm} / \mathrm{min}$. Diharapkan mesin ini bisa menyokong industri kreatif styrofoam di Indonesia.
\end{abstract}

Kata kunci-styrofoam, hot cutting pen, kontrol PID.

\section{PENDAHULUAN}

$\mathrm{P}$ ERKEMBANGAN industri kreatif semakin pesat akhirakhir ini. Salah satu contohnya adalah industri kreatif dalam pembuatan dekorasi dari styrofoam [1]. Dekorasi dari styrofoam bisa digunakan dalam banyak hal, seperti: ucapan selamat pada pernikahan, wisuda, promosi jabatan; ucapan bela sungkawa, tugas senirupa siswa, pembuatan bantalan pengaman barang, dekorasi pada acara karnaval, festifal budaya, dan lain-lain.

Alat pemotongan styrofoam ada yang bersifat manual dan otomatis. Contoh alat pemotong styrofoam manual yaitu cutter dan hot wire [2]. Saat ini banyak pengrajin styrofoam di Indonesia yang menggunakan alat pemotong styrofoam manual, seperti yang terjadi di pasar bunga dan styrofoam di Jalan Koyan, Gubeng, Surabaya. Pemotongan styrofoam secara manual yang baik dan terencana melibatkan serangkaian aktivitas lain sebagai penunjang yang mendukung misalnya pengukuran, sketsa, dan lain-lain. Selain itu, apabila dituntut bentuk pemotongan yang seragam dalam jumlah yang cukup banyak, akan menjadi masalah karena perlu konsistensi dalam pengukuran, sketsa, dan pemotongan

Untuk mengatasi masalah tersebut, terdapat alat pemotong otomatis seperti CNC hot wire [3][4] yang saat ini telah dipasarkan di Indonesia. Mesin $C N C$ hot wire bekerja secara otomatis dengan menginputkan file g-code dari komputer kemudian mesin $C N C$ hot wire dapat bergerak otomatis sesuai dengan input g-code. Akan tetapi, CNC hot wire yang ada saat ini tidak dilengkapi dengan sistem kontrol suhu otomatis sehingga saat proses pemotongan semakin lama suhu pada hot wire turun karena kalor merambat pada styrofoam [5]. Suhu yang tidak konsisten dapat mengakibatkan hasil pemotongan yang kurang rapi dan kerf width [6] tidak konsisten. Selain itu, hot wire kurang efektif untuk memotong styrofoam karena hanya bisa melakukan pemotongan dua dimensi, sehingga pemotongan harus dimulai dari tepi dan keluar lagi melalui jalur awal. Hal ini menjadi masalah apabila desain styrofoam yang dibentuk memiliki tepi bersambung seperti huruf $\mathrm{O}$ dan $\mathrm{P}$.

Oleh karena itu, pada penelitian ini penulis membuat mesin pemotong styrofoam 3 axis menggunakan hot cutting pen yang dapat memotong dari starting point manapun sesuai dengan kehendak operator, sehingga bisa memotong lebih efektif dan styrofoam sisa tetap bisa digunakan. Pada hot cutting pen terdapat sensor suhu dan sistem kontrol suhu menggunakan metode PID agar selama proses pemotongan suhu tetap stabil. Suhu yang stabil akan menghasilkan potongan yang rapi dan konsisten. Mikrokontroler yang digunakan adalah Arduino Nano untuk menghemat biaya dan daya. Diharapkan mesin ini bisa menyokong industri kreatif styrofoam di Indonesia.

\section{DASAR TEORI}

\section{A. Motor Stepper}

Motor stepper adalah perangkat elektromekanis yang bekerja dengan mengubah pulsa elektronis menjadi gerakan mekanis diskrit [7]. Motor stepper tidak dapat bergerak sendirinya, tetapi bergerak secara per-step sesuai dengan spesifikasinya, dan bergerak dari satu step ke step berikutnya memerlukan waktu, serta menghasilkan torsi yang besar pada kecepatan rendah. Motor stepper juga memiliki karakteristik yang lain yaitu torsi penahan, yang memungkinkan menahan posisinya. Hal ini sangat berguna untuk aplikasi dimana suatu sistem memerlukan keadaan start dan stop. Motor stepper tidak merespon sinyal clock dan mempunyai beberapa lilitan dimana lilitan-lilitan tersebut harus dicatu tegangan dahulu dengan suatu urutan tertentu agar dapat berotasi. Membalik urutan pemberian 
tegangan tersebut akan menyebabkan putaran motor stepper yang berbalik arah. Jika sinyal kontrol tidak terkirim sesuai dengan perintah maka motor stepper tidak akan berputar secara tepat, mungkin hanya akan bergetar dan tidak bergerak. Besarnya derajat putaran per step adalah parameter terpenting dalam pemilihan motor stepper karena akan menentukan ukuran langkah gerakan yang paling kecil. Tiap-tiap motor stepper mempunyai spesifikasi masing-masing, antara lain $0.72^{\circ}$ per step, $1.8^{\circ}$ per step, $3.6^{\circ}$ per step, $7.5^{\circ}$ per step, $15^{\circ}$ per step, dan bahkan ada yang $90^{\circ}$ per step.

Ada tiga mode eksitasi yang biasa digunakan untuk motor stepper, yaitu fullstep, halfstep, dan Microstepping. Dalam operasi fullstep, motor bergerak sesuai dengan spesifikasi derajat per stepnya, yaitu motor $1,8^{\circ}$ untuk motorstepper bipolar yang digunakan dalam penelitian ini dan memerlukan 200 langkah per satu putaran motor. Ada dua jenis mode eksitasi fullstep, yaitu eksitasi fasa tunggal dan fasa ganda. Dalam fullstep fasa tunggal, motor dioperasikan hanya dengan satu fase (kelompok gulungan) yang diberi energi sekaligus. Mode ini membutuhkan daya paling sedikit dari pengemudi mode eksitasi manapun. Dalam mode dual phase, motorstepper dioperasikan dengan kedua fase berenergi pada saat bersamaan. Sedangkan eksitasi Half Step adalah operasi fasa tunggal dan ganda bergantian yang menghasilkan langkah-langkah setengah sudut langkah dasar. Karena sudut langkah yang lebih kecil, mode ini memberikan dua kali resolusi dan operasi yang lebih halus. Half Stepping menghasilkan torsi kira-kira 15\% lebih sedikit daripada dual phase Full Stepping. Modifikasi Half Stepping menghilangkan torsi ini dengan meningkatkan arus yang diaplikasikan ke motor saat fase tunggal diberi energi.Sedangkan Microstepping adalah teknik yang meningkatkan resolusi motorik dengan mengendalikan baik arah dan amplitudo aliran arus pada masing-masing lilitan [8]. Arus proporsional dalam gulungan sesuai dengan fungsi sinus dan kosinus. Microstepping bisa membagi langkah dasar motor hingga 256 kali. Pada penelitian ini, tipe motor stepper yang digunakan adalah bipolar yang memiliki jumlah step dalam satu kali putaran yaitu 200 step. Dengan menggunakan mode Microstepping, maka step dapat dibagi lagi sehingga jumlah step dalam satu kali putaran rotor pada motor stepper menjadi 1600 step. Hal ini karena satu step dari dasar gerakan motor stepper dibagi delapan dengan metode Microstepping.

\section{B. Kontrol PID}

Sistem Kontrol PID (Proportional-Derivative-Integratif) merupakan kontroler untuk menentukan presisi suatu sistem instrumentasi dengan karakteristik adanya umpan balik pada sistem tesebut (Feed back) [9]. Sistem kontrol PID terdiri dari tiga buah cara pengaturan yaitu kontrol P (Proportional), D (Derivative) dan I (Integral), dengan masing-masing memiliki kelebihan dan kekurangan. Dalam implementasinya masingmasing cara dapat bekerja sendiri maupun gabungan diantaranya kontrol P, PI, dan PID. Dalam perancangan sistem kontrol PID yang perlu dilakukan adalah mengatur parameter P, I atau D agar tanggapan sinyal keluaran sistem terhadap masukan tertentu sebagaimana yang diinginkan.

Kontrol PID menghasilkan sinyal kontrol yang sebanding dengan sinyal error (aksi proporsional), sebanding dengan total sinyal error (aksi integral), dan sebanding dengan turunan dari kesalahan yang sekarang dengan kesalahan yang sebelumnya (aksi derivative). Sinyal error merupakan selisih antara set point dengan nilai keluaran aktual. Kontrol PID dapat ditulis menjadi bentuk matematis seperti pada persamaan (1).

$$
u(t)=K p \cdot e(t)+K d \cdot \frac{d}{d t} e(t)+K i \cdot \int e(t) d t
$$

Pada persamaan 2.1, u(t) merupakan sinyal kontrol PID dan $\mathrm{e}(\mathrm{t})$ merupakan sinyal error. Sedangkan $\mathrm{Kp}, \mathrm{Ki}$, dan $\mathrm{Kd}$ masing-masng merupakan koefisien. Untuk sistem diskrit, persamaan 2.1 dimodifikasi menjadi persamaan 2 .

$u[n]=K p \cdot e[n]+K d \cdot(e[n]-e[n-1])+K i \cdot \sum e[n]$

Nilai $\mathrm{Kp}, \mathrm{Ki}$, dan $\mathrm{Kd}$ pada penelitian ini akan dicari menggunakan tuning manual. Sinyal kontrol yang akan dihasilkan berupa PWM untuk menggerakkan motor agar mengarah ke posisi yang diinginkan.

\section{PERANCANGAN SISTEM}

Pada tahap ini, akan dijelaskan mengenai perancangan sistem mesin pemotong Styrofoam secara keseluruhan. Gambaran sistem secara keseluruhan diilustrasikan pada blok diagram sistem seperti pada gambar 1, yang meliputi: hubungan antara input desain, software converter, mikrokontroller, motor stepper, dan kontrol suhu PID.

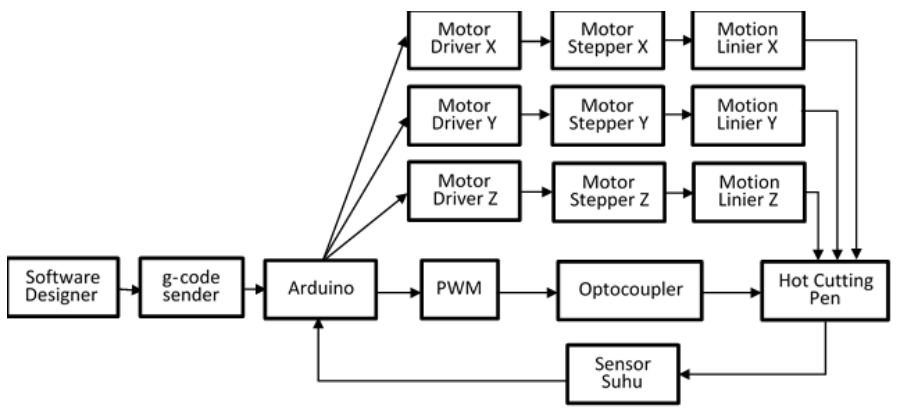

Gambar 1. Diagram Blok Sistem

Pada dasarnya, sistem terdiri dari software dan hardware. Software pada mikrokontroller berupa program untuk menjalankan semua motor stepper sesuai input dari g-code, juga untuk melakukan kontrol suhu pada aktuator. Sedangkan hardware terdiri hardware mekanik dan hardware elektronik. Hardware mekanik berupa kerangka mesin yang sesuai dengan perancangan mekanik, dan hardware elektronik terdiri dari power supply, kontroler, driver motor, motor stepper, sensor suhu, gate driver, dan aktuator.

Pada perancangan mekanik, dilakukan survei pasar mengenai ketebalan dan dimensi dari Styrofoam yang biasa dijual. Setelah dilakukan survey pasar, didapatkan hasil bahwa Styrofoam biasa dijual dengan variasi ketebalan $1 \mathrm{~cm}, 1,5 \mathrm{~cm}$, $2 \mathrm{~cm}, 3 \mathrm{~cm}, 4 \mathrm{~cm}, 5 \mathrm{~cm}, 6 \mathrm{~cm}, 8 \mathrm{~cm}$, dan $10 \mathrm{~cm}$. Sedangkan dimensi Styrofoam yang biasa dijual adalah $40 \times 60 \mathrm{~cm}$, $60 \times 80 \mathrm{~cm}, 60 \times 100 \mathrm{~cm}, 80 \times 100 \mathrm{~cm}, 100 \times 100 \mathrm{~cm}, 100 \times 150 \mathrm{~cm}$, dan $200 x 200 \mathrm{~cm}$. Dari hasil survey pasar, ditentukan dimensi kerja dari alat yaitu sebesar $100 \mathrm{~cm}$ x $100 \mathrm{~cm}$ dengan panjang lintas aksis Z sebesar $11,5 \mathrm{~cm}$ seperti pada gambar 2 . 


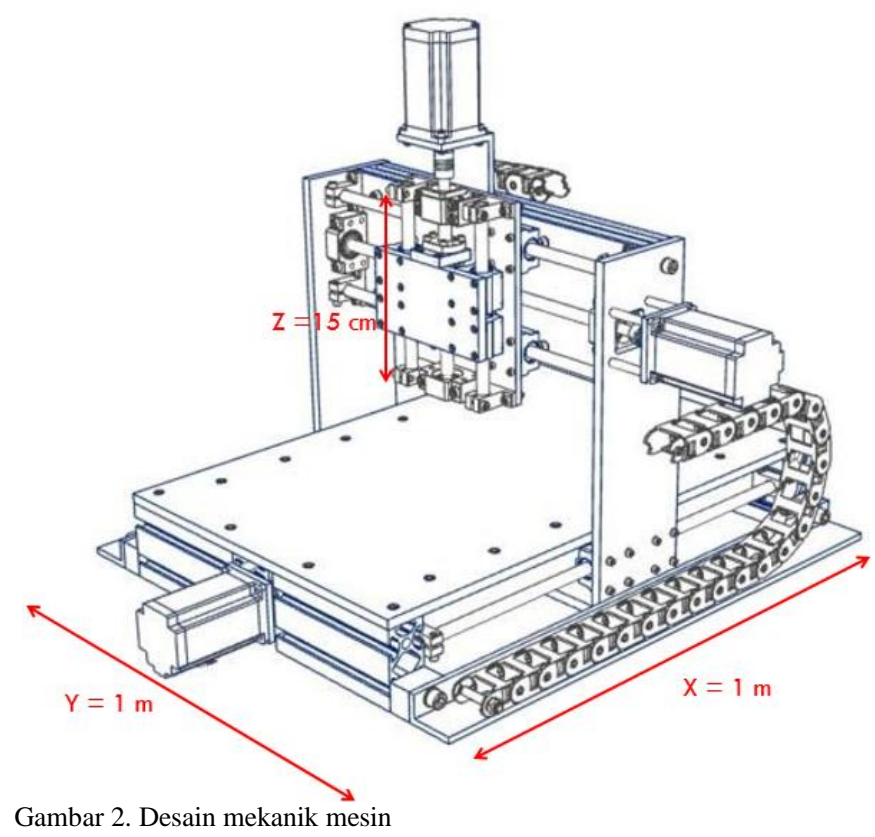

\section{PENGUJIAN DAN PEMBAHASAN}

\section{A. Pengujian Kalibrasi Aksis}

Pada tahap ini, dilakukan pegujian kalibrasi aksis yang bertujuan agar mesin pemotong styrofoam dapat menempuh jarak yang sesuai dengan jarak yang di inputkan. Kalibrasi aksis dilakukan dengan cara menyesuaikan jumlah step / mm dari setiap motor stepper di setiap aksis. Hasil kalibrasi aksis pada sumbu Y dapat dilihat pada tabel 1.

Tabel 1.

Uji arah putar motor stepper aksis Y

\begin{tabular}{ccccc}
\hline \hline UJI & $\begin{array}{c}\text { TARGET } \\
\text { KE }\end{array}$ & $\begin{array}{c}\text { RESOLUSI } \\
(\mathrm{mm})\end{array}$ & $\begin{array}{c}\text { HASIL } \\
(\mathrm{mm})\end{array}$ & $\begin{array}{c}\text { RESOLUSI } \\
\text { BENAR }(\text { step/mm })\end{array}$ \\
\hline 1 & 300 & 50 & 703 & 21.3371266 \\
2 & 300 & 25 & 351 & 21.36752137 \\
3 & 300 & 21.35 & 299 & 21.42140468 \\
4 & 400 & 21.35 & 400.5 & 21.32334582 \\
5 & 500 & 21.35 & 501 & 21.30738523 \\
6 & 600 & 21.35 & 600 & 21.35 \\
7 & 700 & 21.35 & 700 & 21.35 \\
8 & 800 & 21.35 & 800 & 21.35 \\
\hline \hline
\end{tabular}

Keterangan:

Target = ukuran panjang gerakan yang di inputkan $(\mathrm{mm})$ Resolutsi $=$ jumlah step dari motor stepper tiap millimeter (step/mm)

Hasil = lintasan nyata yang ditempuh $(\mathrm{mm})$

Resolusi benar $=$ resolusi sebenarnya $(\mathrm{step} / \mathrm{mm})$

Pada uji ini, di inputkan gerakan dengan panjang tertentu yang disebut target. Resolusi memiliki nilai awal $50 \mathrm{step} / \mathrm{mm}$. Setelah di masukkan gerakan dengan nilai tertentu, didapatkan lintasan nyata yang ditempuh. Setelah didaptkan lintasan nyata yang ditempuh (hasil), maka dilakukan perhitungan resolusi sebenarnya seperti pada persamaan 3 .

RESOLUSI BENAR $=($ RESOLUSI/HASIL $) \times T A R G E T$
Setelah pengujian kalibrasi aksis Y dilakukan sebanyak lima kali, didapatkan lima nilai RESOLUSI BENAR yang memiliki nilai yang berdekatan. Untuk menentukan RESOLUSI BENAR yang akan digunakan pada uji selanjutnya, kelima nilai RESOLUSI BENAR di rata-rata dengan cara dijumlah total dan dibagi lima. Maka, didapatkan hasil nilai RESOLUSI BENAR sebesar $21,35 \mathrm{~mm} / \mathrm{step}$ dan digunakan pada uji ke 6, 7, dan 8 . Dengan menggunakan RESOLUSI sebesar 21,35, didapatkan HASIL yang sama dengan TARGET. Maka diputuskan bahwa nilai RESOLUSI untuk motor stepper pada aksis $\mathrm{Y}$ adalah 21,35. Untuk selanjutnya, uji pada aksis $\mathrm{X}$ dan $\mathrm{Z}$ juga menggunakan RESOLUSI sebesar 21,35 dan didapatkan hasil jarak input sesuai dengan jarak tempuh aktuator sebenarnya karena juga menggunakan motor stepper bipolar.

\section{B. Tuning PID dan Uji Kontrol Suhu Aktuator}

Pada tahap ini, dilakukan tuning dengan metode ZieglerNicholes. Pada metode ini, hanya dimasukkan nilai Kp sebagai gain kritis (Kcr), kemudian dicari grafik dengan osilasi yang konsisten. Pertama, dimasukkan nilai $\mathrm{Kcr}=0.5$ dan dihasilkan grafik seperti pada gambar 3 .

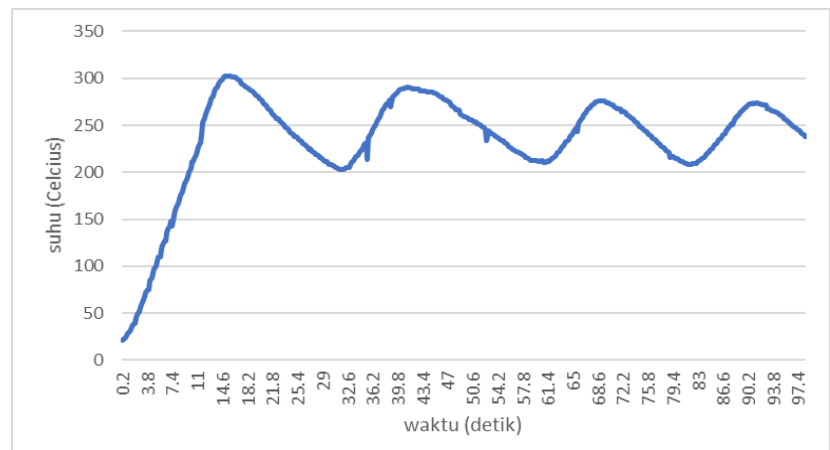

Gambar 3. Grafik suhu dengan Kcr=0.5

Grafik pada gambar 3 menunjukkan osilasi yang semakin menurun. Menurut teori Ziegler-Nicholes, hal ini karena gain kritis (Kcr) nya terlalu kecil. Maka dilakukan uji lagi dengan menaikan gain kritis dengan nilai 1, 2, 3, 4, dan 5. Namun lamakelamaan osilasi masih semakin turun. Setelah dimasukkan nilai $\mathrm{Kcr}=6$, dihasilkan grafik osilasi yang cukup konsisten seperti pada gambar 4.

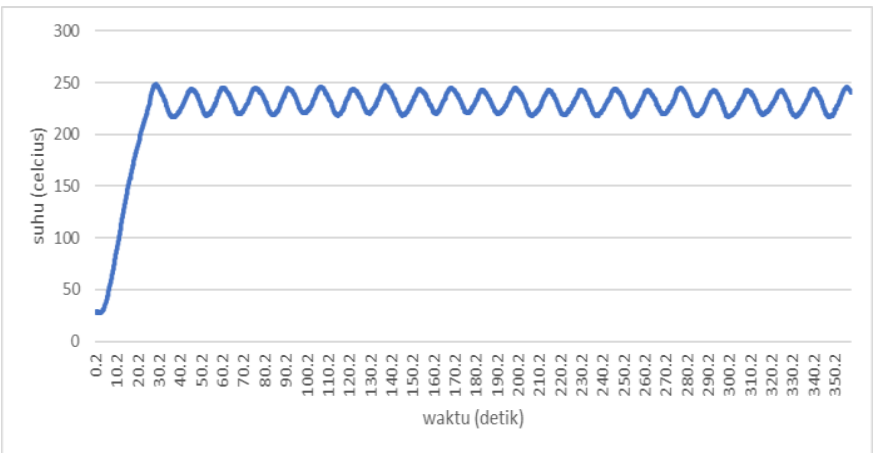

Gambar 4. Grafik suhu dengan Kcr=6

Grafik pada gambar 4 menunjukkan osilasi yang konsisten. Maka, ditentukan Kcr=6 sebagai gain kritis dari metode Ziegler-Nicholes kemudian dihitung nilai Kp, Ki, dan Kd sesuai dengan rumus pada tabel 2 . 
Tabel 2.

Rumus variable PID metode Ziegler-Nicholes

\begin{tabular}{cccc}
\hline \hline Tipe Kontroller & $\mathrm{Kp}$ & $\mathrm{Ki}$ & $\mathrm{Kd}$ \\
\hline $\mathrm{P}$ & $0.5 \mathrm{Kcr}$ & $\infty$ & 0 \\
$\mathrm{I}$ & $0.45 \mathrm{Kcr}$ & $(1 / 1.2) \mathrm{Pcr}$ & 0 \\
$\mathrm{D}$ & $0.6 \mathrm{Kcr}$ & $0.5 \mathrm{Pcr}$ & $0.125 \mathrm{Pcr}$ \\
\hline \hline
\end{tabular}

Dari rumus variable PID dengan metode Ziegler-Nicholes, maka didapatkan hasil $\mathrm{Kp}=3,6, \mathrm{Ki}=7,78$, dan $\mathrm{Kd}=0,1945$. Kemudian nilai ini dimasukkan pada program PID pada mikrokontroler dan dihasilkan grafik seperti pada gambar 5 .

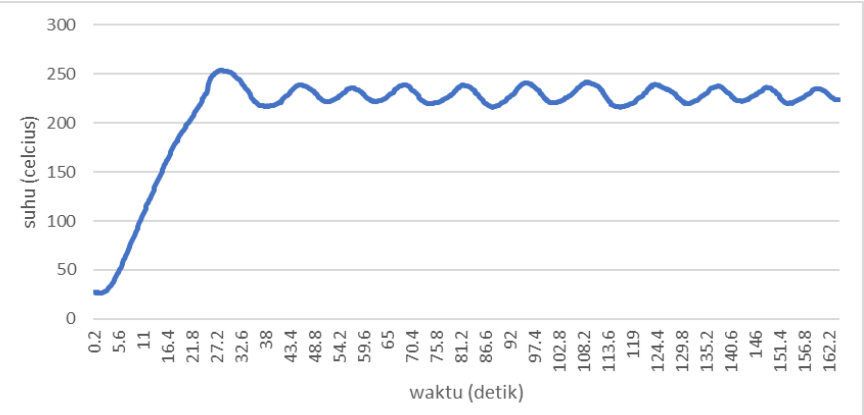

Gambar 5. Grafik suhu dengan metode Ziegler-Nicholes

Gambar 6 menunjukkan grafik hasil pembacaan suhu aktuator namun masih memiliki lebar jarak osilasi yang cukup besar yaitu 20 derajat celcius. Maka dari itu dilakukan tuning PID untuk memperkecil lebar osilasi.

\section{- $\quad$ Tuning PID}

Pada tuning PID, nilai Kd dibuat tetap dan yang diubah adalah nilai Kp dan Ki untuk memperkecil lebar osilasi. Nilai Kp dibuat 4,2, $\mathrm{Ki}=24$, dan $\mathrm{Kd}=1,945$ dan dihasilkan lebar osilasi sebesar 11 derajat celcius. Maka ditentukan nilai tersebut sebagai variable PID. Grafik pembacaan suhu dapat dilihat pada gambar 6.

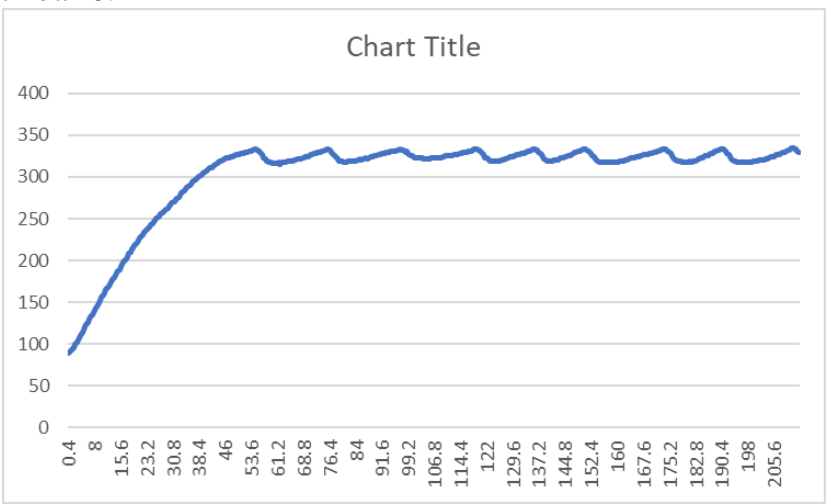

Gambar 6. Grafik suhu dengan tuning PID

\section{Uji Pemotongan Styrofoam}

Pengujian ini dilakukan dengan tujuan mencari nila feed rate dan suhu yang tepat untuk memotong styrofoam dengan ketebalan berbeda. Pengujian dilakukan dengan melakukan pemotongan styrofoam dengan hot cutting pen dengan bentuk memanjang sebesar $5 \mathrm{~cm}$ dan dilakukan empat kali pada setiap pengaturan suhu set point dan feed rate. Styrofoam yang digunakan untuk uji pemotongan memiliki ketebalan $1 \mathrm{~cm}$, $1,5 \mathrm{~cm}, 2 \mathrm{~cm}$, dan $3 \mathrm{~cm}$ karena styrofoam dengan ketebalan inilah yang biasa dipakai untuk industri kreatif styrofoam di pasar Indonesia.

- Uji Pemotongan Styrofoam $1 \mathrm{~cm}$
Pada uji pemotongan styrofoam dengan ketebalan $1 \mathrm{~cm}$, digunakan pengaturan feed rate $200 \mathrm{~mm} / \mathrm{min}$ dan suhu set point $230^{\circ}$ C. Pada uji pemotongan ini didapatkan hasil sebagai berikut:

Aktuator tertinggal, bengkok

$>$ Banyak jaring-jaring styrofoam pada sisa potongan

$>$ Banyak jaring-jaring styrofoam pada aktuator

Hasil tersebut masih belum bagus seperti yang terlihat pada gambar 7. Maka dari itu, dilakukan uji ulang dengan menambahkan suhu sebesar $10^{\circ} \mathrm{C}$ pada setiap pengujian hingga didapatkan hasil yang optimal.

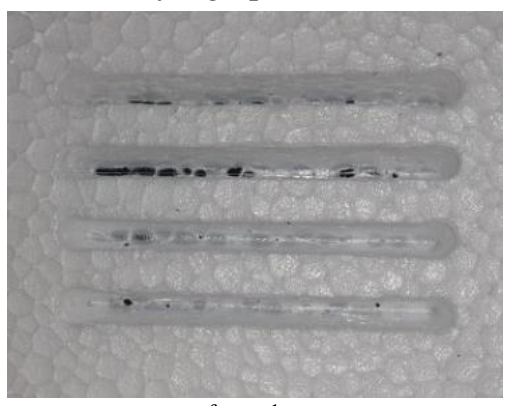

Gambar 7. Uji 1 pemotongan styrofoam $1 \mathrm{~cm}$

Setelah dilakukan uji kelima dengan menggunakan feed rate $200 \mathrm{~mm} / \mathrm{min}$ dan suhu set point $270^{\circ} \mathrm{C}$, didapatkan hasil sebagai berikut:

$>$ Aktuator sedikit tertinggal

$>$ Ada jaring-jaring styrofoam pada sisa potongan

$>$ Ada jaring-jaring styrofoam pada aktuator

Hasil tersebut sudah bagus dan optimal seperti terlihat pada gambar 8. Maka dari itu, disimpulkan bahwa untuk memotong styrofoam dengan ketebalan $1 \mathrm{~cm}$ dengan feed rate $200 \mathrm{~mm} / \mathrm{min}$ diperlukan suhu minimal $270^{\circ} \mathrm{C}$.

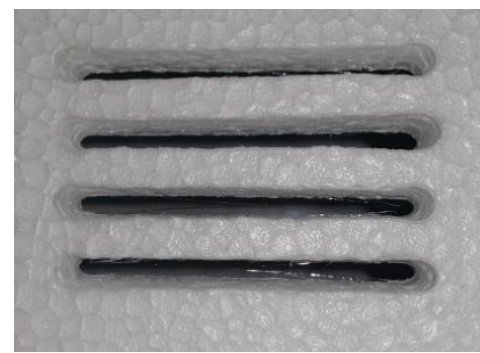

Gambar 8. Hasil pemotongan styrofoam $1 \mathrm{~cm}$

Setelah didapatkan suhu minimal untuk memotong styrofoam dengan ketebalah $1 \mathrm{~cm}$ dengan feed rate 200 $\mathrm{mm} / \mathrm{min}$, selanjutnya dilakukan uji pemotongan styrofoam dengan feed rate yang lebih tinggi agar proses pemotongan bisa dilakukan lebih cepat, yaitu $250 \mathrm{~mm} / \mathrm{min}$ dan $300 \mathrm{~mm} / \mathrm{min}$. Setelah dilakukan uji pemotongan dengan meningkatkan feed rate, didapatkan hasil pemotongan bagus pada feed rate 250 $\mathrm{mm} / \mathrm{min}$ dengan suhu $280^{\circ} \mathrm{C}$ dan pada feed rate $300 \mathrm{~mm} / \mathrm{min}$ dengan suhu $290^{\circ} \mathrm{C}$. Maka agar didapatkan hasil optimal digunakan feed rate $300 \mathrm{~mm} / \mathrm{min}$ dan $290^{\circ} \mathrm{C}$ untuk memotong styrofoam $1 \mathrm{~cm}$ karena semakin cepat proses pemotongan, maka akan menghemat waktu dan energi listrik yang diperlukan untuk mengoperasikan mesin dan komputer.

- Uji Pemotongan Styrofoam 1,5 cm

Pada uji pemotongan styrofoam dengan ketebalan $1,5 \mathrm{~cm}$, digunakan pengaturan feed rate $300 \mathrm{~mm} / \mathrm{min}$ dan suhu set point 
$290^{\circ}$ C. Akan tetatapi, hasilnya masih belum optimal karena aktuator sedikit tertinggal dan masih ada jarring-jaring sisa potongan. Maka dari itu, dilakukan uji ulang dengan meningkatkan suhu set point menjadi $30^{\circ} \mathrm{C}$. Setelah dilakukan pemotongan, didapatkan hasil yang optimal seperti terlihat pada gambar 9. Maka dari itu, disimpulkan bahwa untuk memotong styrofoam dengan ketebalan $1,5 \mathrm{~cm}$ dengan feed rate 300 $\mathrm{mm} / \mathrm{min}$ diperlukan suhu minimal $300^{\circ} \mathrm{C}$.

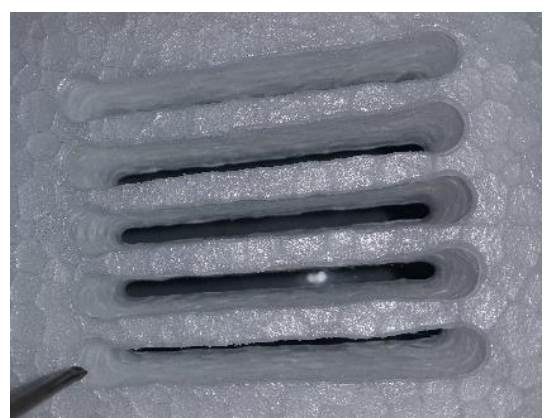

Gambar 9. Uji pemotongan styrofoam $1,5 \mathrm{~cm}$

- Uji Pemotongan Styrofoam $2 \mathrm{~cm}$

Pada uji pemotongan styrofoam $2 \mathrm{~cm}$, digunakan pengaturan feed rate $300 \mathrm{~mm} / \mathrm{min}$ dan suhu set point $300^{\circ} \mathrm{C}$. Namun didapatkan hasil yang kurang optimal karena masih ada sedikit sisa jarring-jaring styrofoam sehingga suhu set point ditingkatkan menjadi $310^{\circ} \mathrm{C}$ dan didapatkan hasil potongan rapi seperti pada gambar 10 .

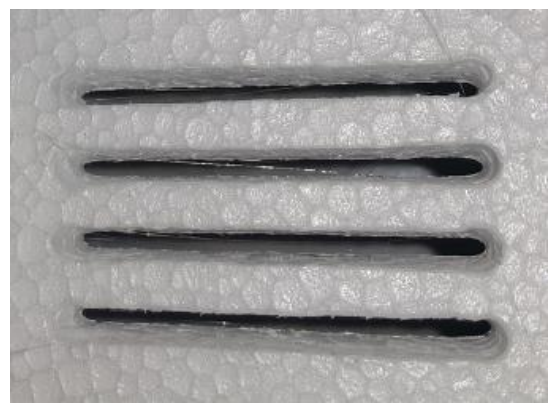

Gambar 10. Uji pemotongan styrofoam $2 \mathrm{~cm}$

- Uji Pemotongan Styrofoam $3 \mathrm{~cm}$

Pada uji pemotongan styrofoam $3 \mathrm{~cm}$, digunakan pengaturan feed rate $300 \mathrm{~mm} / \mathrm{min}$ dan suhu set point $320^{\circ} \mathrm{C}$. Namun didapatkan hasil yang kurang optimal karena masih ada sedikit sisa jarring-jaring styrofoam sehingga suhu set point ditingkatkan menjadi $330^{\circ} \mathrm{C}$ dan didapatkan hasil potongan rapi seperti pada gambar 11.

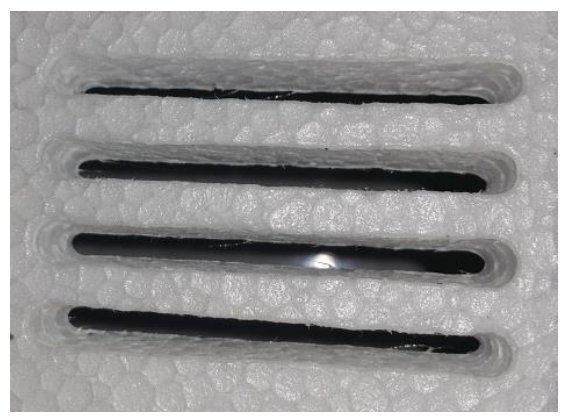

Gambar 11. Uji pemotongan styrofoam $3 \mathrm{~cm}$

\section{Uji Pemotongan Styrofoam dengan G-code}

Setelah dilakukan uji pemotongan untuk mencari suhu dan feed rate optimal untuk memotong styrofoam, dilakukan uji pemotongan styrofoam menggunakan g-code. File g-code kemudian di masukkan kedalam GUI Universal G-code Sender dan dilihat hasil visualisasinya seperti pada gambar 12. Pada jendela visualisasi terdapat garis kuning yang merepresentasikan posisi aktuator dan akan bergerak sesuai dengan gerakan aktuator. Setelah hasil visualisasi sesuai dengan desain pada software dasainer, maka file g-code dikirim kepada mikrokontroler dan proses pemotongan berjalan secara otomatis.

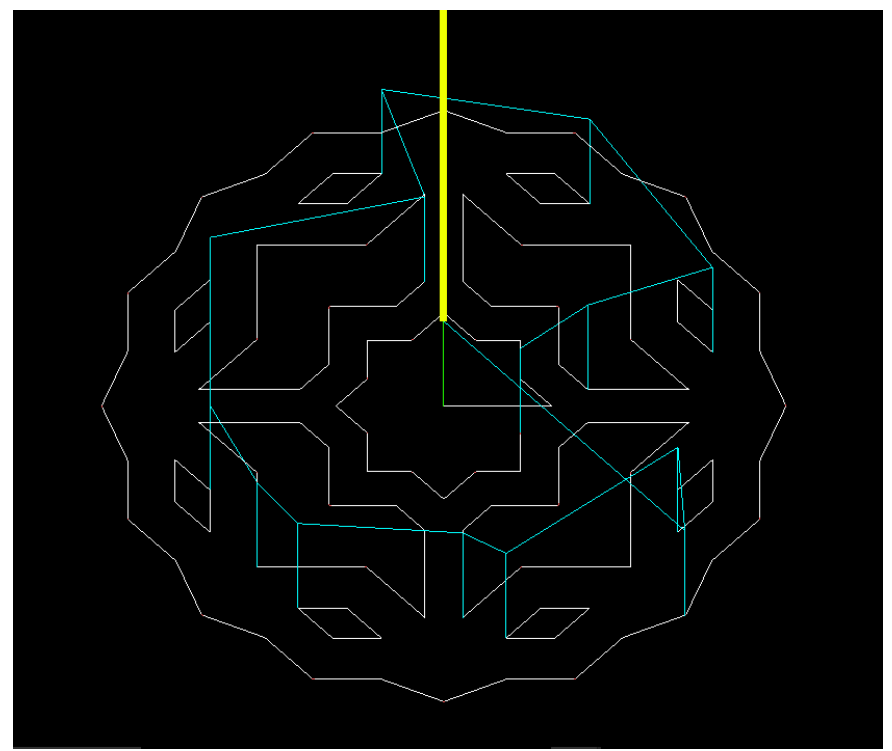

Gambar 12. Visualisasi file g-code

Setelah proses pemotongan selesai, didapatkan hasil pemotongan yang rapi dan bentuk sesuai dengan desain g-code yang di inputkan. Hasil styrofoam yang telah di potong dapat dilihat pada gambar 13 .

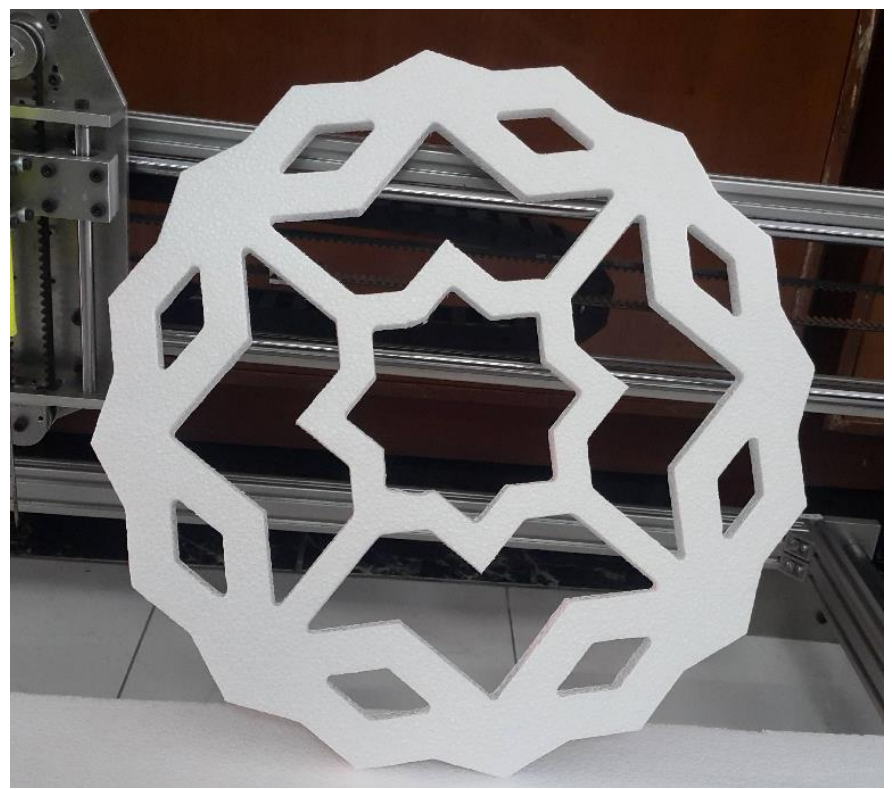

Gambar 13. Hasil pemotongan styrofoam dengan g-code 


\section{KESIMPULAN}

Berdasarkan perancangan, pembuatan dan pengujian keseluruhan sistem pada alat penelitian ini dapat disimpulkan beberapa hal sebagai berikut:

- Penggunaan hot cutting pen pada mesin 3 axis untuk memotong styrofoam memiliki kelebihan dapat membentuk styrofoam tanpa memotong salah satu sisi styrofoam, namun memiliki kerf width yang cukup lebar yaitu sekitar $3 \mathrm{~mm}$.

- Kontrol suhu dengan metode PID menggunakan ZieglerNicholes menghasilkan nilai optimum dengan $\mathrm{Kp}=3,6$, $\mathrm{Ki}=7,78$, dan $\mathrm{Kd}=0,1945$ dan lebar osilasi $20^{\circ} \mathrm{C}$.

- Tuning PID menggunakan metode Trial-Error berdasarkan hasil Ziegler-Nicholes menghasilkan nilai optimal dengan $\mathrm{Kp}=4,2, \mathrm{Ki}=24$, dan $\mathrm{Kd}=1,945$ dan range osilasi $11^{\circ} \mathrm{C}$.

- Pemotongan Styrofoam menggunakan hot cutting pen memiliki nilai optimal feed rate $300 \mathrm{~mm} / \mathrm{min}$ dengan suhu $290^{\circ} \mathrm{C}$ untuk ketebalan $1 \mathrm{~cm}, 300^{\circ} \mathrm{C}$ untuk ketebalan 1,5 $\mathrm{cm}, 310^{\circ} \mathrm{C}$ untuk ketebalan $2 \mathrm{~cm}, 330^{\circ} \mathrm{C}$ untuk ketebalan $3 \mathrm{~cm}$.

\section{DAFTAR PUSTAKA}

[1] B. Sulkowski, W. W.; Nowak, K.; Sulkowska, A; Wolinska, A; Bajdur, W. M.; Pentak, D.; Mikula, "Study of the sulfonation of expanded polystyrene waste and of properties of the products obtained," p. 2417-2424, 2009.

[2] Stege, Method of producing test components by a hot wire cutter. Canada Patent CA2744470 A1, 2011.

[3] J. B. and D. P. D. Aitchison, David Aitchison, "An investigation into the prediction of optimal machining conditions for polystyrene foam cut with a taut hot-wire," 2009.

[4] S. N. Cheng, Hot-wire cutter. United States Patent US 8278585 B2, 2012.

[5] M. Aitchison, D.R., Bain, J., Brooks, H., Taylor, "Transient temperature effects in hot-wire plastic foam cutting," in 4th Int. Conf. on Design and Production of Machines \& Dies/Molds, 2007, pp. 219-224.

[6] H. L. B. and D. R. Aitchison, Force feedback temperature control for hot-tool. New Zealand, 2009.

[7] U. M. S.G.Abeyratne, "A new power conversion strategy for a unipolar stepper motor drive," in Power Electronics Specialists Conference, 2006.

[8] M. K. S. S. D. R. Gaan, "Frequency Modulation based Microstepping of Stepper Motor for Real Time Position Tracking Applications," IEEE, 2016.

[9] S. . Basilio, J.C. dan Matos, "Design of PI and PID Controllers with Trancient Performance Specification," IEEE Trans. Educ., vol. 45, no. 4, pp. 364-370, 2002 